\title{
MILITARY INTERVENTION, REGIONAL ORGANIZATIONS, AND HOST-STATE CONSENT
}

\author{
DAVID WIPPMAN*
}

\section{INTRODUCTION}

That consent may validate an otherwise wrongful military intervention into the territory of the consenting state is a generally accepted principle. When a government is both widely recognized and in effective control of most of the state, this principle affords a clear alternative to Security Council authorization as a basis for justifying external intervention, whether by states acting unilaterally, or by states acting under the auspices of the United Nations (U.N.) or a regional organization.

In many cases, however, consent is often a highly controversial justification for military intervention. In some cases, it is doubtful whether the consent at issue is voluntary. ${ }^{1}$ In other cases, the individual purporting to give consent may lack the legal authority to do so. ${ }^{2}$ But these issues, although they may prove difficult to resolve in particular cases, are usually at least nominally susceptible to resolution under generally accepted principles of treaty law dealing with coercion and the representation of states. ${ }^{3}$ More difficult problems

* Associate Professor of Law, Comell Law School. The author would like to thank Professor John H. Barcelo, III, for helpful comments on a prior draft of this Article.

1. As Judge (then Special Rapporteur) Roberto Ago observed in his report to the International Law Commission on state responsibility, consent may be "expressed or tacit, explicit or implicit, provided however that it is clearly established," and is not "vitiated by "defects' such as error, fraud, corruption or violence." Eighth Report on State Responsibility, Document A/CN.4/318 and Add.1-4, 2 Y.B. INT'L L. COMM'N 3, 35-36 (1979).

2. To be valid, "consent. . . must be internationally attributable to the State; in other words, it must issue from a person whose will is considered, at the international level, to be the will of the State and, in addition, the person in question must be competent to manifest that will in the particular case involved." Id. at 36.

3. See id. "The principles which apply to the determination of the validity of treaties also apply with respect to the validity of consent to an action which would, in the absence of such consent, be internationally wrongful."); John Lawrence Hargrove, Intervention by Invitation and the Politics of the New World Order, in LAW AND FORCE IN THE NEW INTERNATIONAL ORDER 113, 119 (L. Damrosch \& D. Scheffer eds., 1991) (legal issues regarding the genuine- 
arise when the authority of a particular government purporting to consent to intervention on behalf of the state is subject to challenge, either because the government has lost control of a substantial portion of the state, or because the government's international legitimacy is otherwise subject to doubt.

The theoretical basis for the rule that consent may validate an otherwise wrongful intervention is not entirely clear. In a study of state responsibility for wrongful conduct, the International Law Commission concluded that consent to intervention acts as a form of bilateral agreement between the consenting and intervening states that suspends the normal operation of the legal rules that would otherwise govern their relationship. ${ }^{4}$ It seems more plausible, however, to conclude simply that consent or its absence is central to the definition of wrongful intervention in the first place. In other words, prohibited intervention should be understood as intervention against the will of the state. In Oppenheim's formulation, it is "dictatorial interference" in a state's internal affairs that is impermissible, not external involvement per se.

Consistent with this understanding, many states have attempted to justify military intervention in other states on the basis of consent. In some cases, the justification was relatively persuasive, and the interventions met with general acquiescence. During the Cold War both France, and to a lesser extent the United Kingdom, relied on consent to justify periodic interventions in former colonies to support friendly governments against small-scale rebellions or palace coups. ${ }^{6}$ Most states accepted such interventions, even when the invitations at

ness of invitations to intervene "are resolvable on the basis of familiar concepts drawn straightforwardly from other areas of the law than those having to do directly with restraints on the exercise of force, for example, the law of treaties."); see also Vienna Convention on the Law of Treaties, U.N. Doc. A/CONF. $39 / 27$ (1969), art. 51 (rejecting the validity of consent based on coercion of a state's representative); $i d$. art. 52 (rejecting the validity of consent based on coercion of the state itself); $i d$. art. 7 (identifying individuals presumptively capable of expressing a state's consent to be bound to a treaty).

4. See Roberto Ago, Eighth Report on State Responsibility, supra note 1, at 31-32.

5. 1 L. OPPENHEIM, INTERNATIONAL LAW 305 (H. Lauterpacht ed., 8th ed. 1955) (defining prohibited intervention as "dictatorial interference ... in the affairs of another State for the purpose of maintaining or altering the actual condition of things.").

6. In 1964, Britain intervened in Tanganyika, Uganda, and Kenya to help incumbent governments quell local disturbances and mutinies in the armed forces. See Louise DoswaldBeck, The Legal Validity of Military Intervention by Invitation of the Government, 1985 BRTT.Y.B. INT'L L. 189, 189 n.4 (1986). France intervened more than a dozen times in its African colonies, usually, though not always, to assist beleaguered governments to retain or to resume control in the face of attempted military coups. See John Darnton, The World: Intervening with Elan and No Regrets, N.Y. TIMES, June 26, 1994, § 4, at 3. 
issue arguably came after the inviting officials had already lost their hold on power. ${ }^{7}$ Similarly, the 1982 deployment of United States, French, Italian and British forces to assist the Lebanese government in restoring order met with little international opposition, at least at the outset. ${ }^{8}$

In other cases, reliance on consent proved unpersuasive. For example, when the Soviet Union invoked the principle of state consent to justify invasions of Hungary in 1956, Czechoslovakia in 1968, and Afghanistan in 1979, it met with widespread criticism on the ground that the invitations at issue were either manufactured or coerced. ${ }^{9}$ Similarly, when the United States sent troops to the Dominican Republic in 1965 and to Grenada in 1983, it was condemned by many states which questioned the legal authority of the officials who issued the invitations to intervene. ${ }^{10}$ Still, in these cases, as in those described above, the principle that voluntary consent from proper state authorities can validate intervention was not in dispute.

In most cases, the real issue was, and remains, who is entitled to express the will of the state concerning intervention? Although it is the consent of the state itself that is ultimately at issue, states are abstract entities and cannot by themselves give or withhold consent to intervention. ${ }^{11}$ In general, international law presumes that when a government exercises effective control over the territory and people of the state, the government (and more particularly, the authorized

7. When France intervened against an incumbent government, however, it met with more international criticism than approbation. In 1979, when French troops forcibly deposed the head of state of the Central African Empire, various countries criticized the French action as a violation of the non-intervention principle, despite Bokassa's atrocious human rights record. See W. Michael Reisman, Humanitarian Intervention and Fledgling Democracies, 18 FORDHAM INT'L L.J. 794, 800 (1995).

8. See Doswald-Beck, supra note 6 , at 241-42. Not long after arrival, however, U.S. (and to some extent French) forces were drawn into the conflict in a way that exceeded their status as peacekeepers. As a result, the intervention eventually attracted considerable criticism from other states. See id.

9. See U.N. SCOR, 14th Sess., 746th mtg. at 4, U.N. Doc. S/PV.746 (1956) (Hung.); U.N. SCOR, 23d Sess., 1441st mtg. at 1, U.N. Doc. S/PV.1441 (1968) (Czech.); U.N. SCOR, 35th Sess., 2185th mtg. at 2, U.N. Doc. S/PV.2185 (1980) (Afg.). The interventions were generally deemed invalid. See Rein Mullerson, Intervention by Invitation, in LAW AND FORCE IN THE NEW INTERNATIONAL ORDER 127, 128-29 (L. Damrosch \& D. Scheffer eds., 1991).

10. See Doswald-Beck, supra note 6, at 228, 237 (noting that "[d]iplomatic reaction to the [U.S.] intervention [in the Dominican Republic] was generally unfavourable" and that "the vast majority of States, including the traditional allies of the U.S., characterized the intervention [in Grenada] as illegal.").

11. See Quincy Wright, United States Intervention in the Lebanon, 53 AM. J. INT'L L. 112, 120 (1959). 
officials of that government) possesses the exclusive authority to express the will of the state in its international affairs. ${ }^{12}$ This presumption derives from a mix of practical and theoretical considerations. As a practical matter, states cannot ignore an effective government, whatever its origin or political leanings. Moreover, reliance on effective control as the test for a government's capacity to represent the state offers a reasonably objective and externally verifiable basis for determining governmental authority, thus "inhibiting intervention" by outside states. ${ }^{13}$ As a theoretical matter, effective control serves as a rough proxy for the existence of some degree of congruity between the government and the larger political community of the state, which supports the government's claim to represent the state as a whole. To the extent that the government is unrepresentative, this assumed congruity may be largely fictitious. ${ }^{14}$ But it is nonetheless widely accepted as the only viable basis on which states can conduct international relations in a decentralized system.

In some cases, however, the presumption that the government speaks for the state may break down. In particular, when the government's control over the state is effectively challenged by an internal, armed opposition, the presumption that the government represents the state may become untenable. ${ }^{15}$ Indeed, it is precisely the authority of a particular government to speak for the state as a whole that is called into question by an internal conflict.

Arguably, the U.N. Charter prohibits aid to either government or rebel forces in a civil war, since aid to one side might disrupt the internal play of forces, and thereby violate the political independence of the state and the right of its people to determine their own political future. ${ }^{16}$ During the Cold War, however, most states acted as if

12. See, e.g., Tom J. Farer, Panama: Beyond the Charter Paradigm, 84 AM. J. INT'L L. 503, 510 (1990) (noting "the virtually uniform practice in international relations of treating any group of nationals in effective control of their state as constituting its legitimate government"); RESTATEMENT (THIRD) OF FOREIGN RELATIONS $\$ 210 \mathrm{cmt}$. d (1985).

13. See Farer, supra note 12 , at 511.

14. Cf. Fernando Tesón, Collective Humanitarian Intervention, 17 MICH. J. INT'L L. 323, 332 (1996) (arguing that "[a] rule requiring democratic legitimacy in the form of free adult universal suffrage seems the best approximation to actual political consent and true representativeness").

15. See generally David Wippman, Change and Continuity in Legal Justifications for Military Intervention in Internal Conflicts, 27 CoLUM. HuM. RTS. L. REV. 435 (1996)

16. See, e.g., Oscar Schachter, International Law: The Right of States to Use Armed Force, 82 MiCH. L. REV. 1620, 1641 (1984); John Norton Moore, Legal Standards for Intervention in Intermal Conflicts, 13 GA. J. INT'L \& COMP. L. 191, 196 (1983); see also U.N. CHARTER, art. 2(4). 
international law permitted military aid to an incumbent government, at least when the government could plausibly claim that such aid was needed to offset external assistance given illicitly to opposing forces. ${ }^{17}$ Conversely, most states viewed aid to rebel forces as a violation of the non-intervention principle, even if the rebels portrayed themselves as freedom fighters opposing a dictatorial regime. ${ }^{18}$

Although easy to state, these general rules are often exceptionally difficult to apply. ${ }^{19}$ Moreover, it is not yet clear whether the end of the Cold War will bring about any significant modifications in these rules. Among the issues yet to be resolved are the following: (1) the point at which an incumbent government loses its authority to request external military assistance; (2) the extent to which the collective character of an intervention may alter the applicable legal analysis; (3) whether multiple warring factions may jointly consent to external military intervention; (4) what happens when one or more of those factions wishes to revoke its consent; and (5) whether a state may bind itself in advance to accept military intervention in specified circumstances. These issues are considered below primarily in the context of a regional organization contemplating intervention in a civil conflict.

\section{CONSENT AND ITS PROBLEMS}

In considering the issues noted above, it may be helpful to characterize invitations to intervene by the relative standing of government and rebel forces at the time an invitation to intervene is issued. A review of past cases suggests the following division: (1) cases in which a recognized government exercises control over most of the state; (2) cases in which the government and rebel forces reach a rough equilibrium, with each in control of a substantial portion of the state; (3) cases in which the incumbent government is merely one of

17. See Tom J. Farer, A Paradigm of Legitimate Intervention, in ENFORCING RESTRAINT: Collective INTERVENTION IN INTERNAL Conflicts 316, 319 (L. Damrosch ed., 1993) (during the Cold War, many states "consistently acted as if recognized governments had an unfettered right to seek foreign assistance in crushing domestic rivals").

18. In keeping with this view, the International Court of Justice held that U.S. aid to rebel forces seeking to overthrow the Government of Nicaragua was illegal, noting that the principle of nonintervention "would certainly lose its effectiveness as a principle of law if intervention were to be justified by a mere request for assistance by an opposition group in another State." Military and Paramilitary Activities (Nicar. v. U.S.), 1986 I.C.J. 14, 126 (June 27).

19. See Mullerson, supra note 9, at 127 (noting that application of the rules governing provision of external assistance at the request of a government, though "perfectly clear from the juridical point of view, is in practice nonetheless fraught with dangers from misapplication"). 
several warring factions; and (4) cases in which all semblance of internal order disappears.

\section{A. Government Control}

From a legal standpoint, the simplest cases to analyze are those in which a recognized, incumbent government controls the political apparatus and most of the territory of the state. In such cases, the government ordinarily retains full authority to request external assistance, or even military intervention, to assist it in maintaining control of the state. ${ }^{20}$ The government may seek such assistance from the United Nations, from regional organizations, or from individual states. As the International Court of Justice observed in Nicaragua $v$. United States, intervention is generally "allowable . . . at the request of the government of a State .....21

In some respects, this position is difficult to reconcile with the principle of self-determination. It can be argued that any government forced to call in external military assistance to maintain itself against internal opposition is not genuinely in a position to speak for the state, and that the provision of such assistance by outside states constitutes an impermissible interference with internal political processes. ${ }^{22}$ Further, provision of external aid, even to the government, runs the risk of internationalizing a previously internal conflict. Nonetheless, most states appear to accept the authority of an effective incumbent government to invite external intervention. ${ }^{23}$

Conversely, neither states nor international organizations may lawfully intervene against the will of an effective, incumbent government. In Nicaragua v. United States, the International Court of Justice concluded that intervention at the request of opposition forces, even those characterizing themselves as "freedom fighters," violated

20. See IAN BROWNLIE, INTERNATIONAL LAW AND THE USE OF FORCE BY STATES 327 (1963); Schachter, supra note 16, at 1641-42; Louis Henkin, Use of Force: Law and U.S. Policy, in RIGHT V. MiGHT: INTERNATIONAL LAW AND THE USE OF FORCE 37, 63 (2d ed. 1991). Indeed, aid to the government in such cases does not constitute intervention in the technical sense, since it does not amount to unlawful interference in the state's internal affairs. See Mullerson, supra note 9, at 127.

21. Nicaragua, 1986 I.C.J. at 126.

22. See, e.g., William E. Hall, A TREATISE ON INTERNATional LAW 344-47 (8th ed. 1924); Wright, supra note 11, at 121-122; Mullerson, supra note 9, at 132.

23. See, e.g., Henkin, supra note 20 , at 63 ("[U]pon authentic invitation, a state may introduce military forces into the territory of another to assist the government for various purposes, including maintaining internal order."); Farer, supra note 17, at 319. 
the non-intervention principle. ${ }^{24}$ For the same reason, the U.S. invasion of Panama was widely condemned even though the invasion ousted a dictatorial regime and replaced it with a democratically elected one. ${ }^{25}$

In general, an effective government's right to seek or oppose external intervention does not depend on the manner in which the government acquired power or the manner in which the government exercises power. ${ }^{26}$ But, there are several existing or potentially emerging exceptions to this general rule. First, a government may not authorize external military intervention against a national liberation movement opposing racist or colonial domination. ${ }^{27}$ This exception represents a specific application of the more general principle that a state may not lawfully authorize a foreign state to take any action that would be illegal under international law if undertaken by the authorizing state itself. ${ }^{28}$ As the process of decolonization accelerated in the 1960s and 1970s, a majority of states in the United Nations concluded that action against national liberation movements constituted a violation of the principle of self-determination. ${ }^{29}$ As a result, the usual presumption that the effective government constitutes the sole representative of the state in international affairs was at least partially reversed. ${ }^{30}$ Although the incumbent government could

24. Nicaragua, 1986 I.C.J. at 126.

25. A large majority of the U.N. General Assembly criticized the U.S. invasion as "a flagrant violation of international law and of the independence, sovereignty and territorial integrity of States." G.A. Res. 44/240, U.N. GAOR, 44th Sess., Supp. No.49, 88th plen. mtg. at 52, U.N. Doc. A/44/L.63 and Add. 1 (1989). See generally Louis Henkin, The Invasion of Panama Under International Law: A Gross Violation, 29 CoLUM. J. TRANSNAT'L L. 293 (1991); Ved Nanda, The Validity of United States Intervention in Panama Under International Law, 84 AM. J. INT'L L. 494 (1990).

26. See Brad R. Roth, Governmental Illegitimacy Revisited: 'Pro-Democratic' Armed Intervention in the Post-Bipolar World, 3 TRANSNAT'L L. \& CONTEMP. PROBS. 481, 482 (1993).

27. See HEATHER A. WILSON, INTERNATIONAL LAW AND THE USE OF FORCE BY NATIONAL LIBERATION MOVEMENTS $91-136$ (1988).

28. See Hargrove, supra note 3 , at 116-17 (asserting that state consent cannot validate "activities which would have been unlawful by the [consenting] state if acting alone").

29. See, e.g., Declaration on Principles of International Law concerning Friendly Relations and Co-operation among States in accordance with the Charter of the United Nations, G.A. Res. 2625 (XXV), U.N. GAOR 6th Comm., 25th Sess., Supp. No. 28, 1883 of plen. mtg. at 123, U.N. Doc. A/8082 (1970) (adopted without a vote) ("Every State has the duty to refrain from any forcible action which deprives peoples referred to in the elaboration of the principle of equal rights and self-determination of their right to self-determination and freedom and independence."); WiLSON, supra note 27, at 99-100, 135.

30. See Rein Mullerson \& David J. Scheffer, Legal Regulation of the Use of Force, in BEYOND CONFRONTATION: INTERNATIONAL LAW FOR THE POST-COLD WAR ERA 125-26 (L. Damrosch, G. Danilenko, \& R. Múllerson eds., 1995); W. Michael Reisman, Allocating Com- 
continue to represent the state in most aspects of its international relations, it could not lawfully invite external aid in suppressing the efforts of a liberation movement to overthrow the government. ${ }^{31}$ To the contrary, the liberation movement alone possessed the right to seek external assistance, although there is considerable controversy over whether such assistance could entail aid amounting to a use of force. $^{32}$

Second, it is at best unclear whether a de jure government overthrown in violation of domestic constitutional law may authorize external intervention to re-establish its authority. ${ }^{33}$ The situation arises most commonly in the case of a palace coup, that is, when a small group of military officers engineers the abrupt and forcible ouster of the incumbent head of state. On its face, external military intervention to reinstate the ejected incumbent would seem to constitute impermissible interference in the state's internal affairs. Nonetheless, a number of countries periodically send troops to help ousted leaders return to the presidential palace. In 1964 for example, the United Kingdom came to the aid of President Julius Nyere of Tanganyika. ${ }^{34}$ Nyere headed an elected government that lost control of the capital to mutinous army troops. At Nyere's request, British troops intervened to restore order. The British action went largely unremarked in the United Nations. Similarly, France has frequently intervened militarily in its former colonies to restore de jure governments to power following internal military coups without attracting much adverse comment from other states. ${ }^{35}$

petences to Use Coercion in the Post-Cold War World: Practices, Conditions, and Prospects, in LAW AND FORCE IN THE NEW INTERNATIONAL ORDER 26, 32-34 (L. Damrosch \& D. Scheffer eds., 1991).

31. See generally Wilson, supra note 27 , at $91-136$ (discussing pertinent U.N. resolutions and state practice).

32. See id.

33. See Domingo Acevedo, The Haitian Crisis and the OAS Response: A Test of Effectiveness in Protecting Democracy, in ENFORCING RESTRAINT: COLLECTIVE INTERVENTION IN INTERNAL CONFLICTS 119, 139 (L. Damrosch ed., 1993) ("It is unclear ... whether a de jure government that has only formal but not actual power may invite foreign 'military intervention' for the purpose of removing the de facto regime.").

34. See Reisman, supra note 7, at 796.

35. See Damton, supra note 6, at 3. In 1996, French paratroopers helped the democratically elected but corrupt government of the Central African Republic force mutinous army troops back into their barracks. Although the French intervention was highly unpopular within the Central African Republic itself, most other states paid little attention. See Jim Hoagland, Does Anyone Care About Africa?, DENV. POST, June 2, 1996, at F4. Some states even commended the French action, including a U.S. official who praised the French intervention as "very efficient," and who described France as a "force for stability in Africa." Gus Constantine, France Keeps a Hand in Ex-Colonies: Bangui Mutiny Latest Example of Intervention, 
Several factors appear to account for the apparent acquiescence of most states in actions of this nature. So long as the interventions at issue are swift and small in scale, most states seem willing to ignore the brief discontinuity in the de jure government's effective control of the state. In effect, states treat the coup makers as temporary usurpers whose actions do not fundamentally alter the de jure government's power to speak for the state. This attitude may be attributable in part to a general recognition that political constraints usually preclude the U.N. Security Council from authorizing intervention in such cases, and in part to a sense that the former colonial powers should be allowed leeway to assist their former colonies in maintaining order, even at the cost of some inconsistency with international legal principles.

A third possible exception is a variant of the previous exception, limited, however, to intervention to restore a democratically elected government subjected to an unconstitutional seizure of power by internal forces. The overthrow of the popularly elected government of Haitian President Aristide presents the paradigmatic contemporary example. Aristide became President of Haiti in 1990, following his victory in an internationally monitored and supervised election. ${ }^{36}$ Some months later the Haitian military, alarmed by Aristide's populist rhetoric and reformist policies, staged a military coup and forced Aristide to flee the country. ${ }^{37}$ Had Aristide immediately invited external military intervention, it might conceivably have fallen within the second exception. Aristide, however, was reluctant to invite foreign military forces into Haiti. He did so, grudgingly and obliquely, only after it became clear that months of economic sanctions and diplomatic pressure would fail to dislodge the military junta. ${ }^{38}$ In any event, Aristide's ouster was not the typical palace coup. The officers in charge had substantial support throughout the military and also in a significant, although minority, segment of Haitian society. ${ }^{39}$ Ac-

WASH. TIMES, June 6, 1996, at A12.

36. See Acevedo, supra note 33, at 129-30.

37. See id.

38. See Melita M. Garza, Aristide Can Only Hint He'd Like Armed Help, CHI. TRIB., June $1,1994, \S 1$, at 12 . Aristide's reluctance to invite intervention openly may be attributable in part to the fact that Haitian law, reflecting unhappy prior experience with foreign intervention, made it illegal for a Haitian government official to invite such intervention. See id; see also Deborah Zabarenko, Aristide Thanks U.S., Gets Assurances on Haiti, REUTER, Sept. 21, 1994 (cited in Tesón, supra note 14, at 360 n. 150) (describing Aristide's ambivalent and shifting views on inviting foreign intervention).

39. See Acevedo, supra note 33, at 131 (noting that "traditionally entrenched groups that had always represented the power of wealth, privilege, and violence in Haiti-particularly the 
cordingly, the usurpers could not be summarily dismissed as transient occupants of the Presidential palace whose ouster would have little impact on the Haitian people's right to self-determination.

The argument in favor of permitting intervention based on an invitation from Aristide was simple. As the elected head of state, Aristide represented the people of Haiti as a whole. Following the coup both the United Nations and the Organization of American States (OAS) continued to recognize Aristide as the legitimate head of state, and both repeatedly demanded his reinstatement. ${ }^{40}$ Accordingly, Aristide had a strong claim that he alone was entitled to speak for the state on questions of intervention. ${ }^{41}$ By contrast, the military junta achieved its position by force and maintained that position by terrorizing much of the country. It had no legitimacy, domestic or international, and therefore should have had no authority to speak for the state or to oppose an intervention to restore democracy. ${ }^{42}$ Intervention in this context, goes the argument, would further Haitian self-determination and fulfill the much-heralded, but still emerging, right to democratic governance. ${ }^{43}$

This argument is a powerful one. But, when the U.N. Security Council finally authorized military intervention to restore Aristide to power, it relied primarily on its authority to maintain international peace through coercive measures under Chapter VII of the Charter. ${ }^{44}$ The authorizing resolution implicitly took note of Aristide's consent to intervention, ${ }^{45}$ but the Security Council was evidently unwilling to treat that consent as sufficient in and of itself to permit military ac-

upper classes and the army-viewed Aristide's popular approach as a threat"); Roth, supra note 26, at 511-512 (noting that the "coup leadership ha[d] support in the elected legislature").

40. See, e.g., William M. Berenson, Joint Venture for the Restoration of Democracy in Haiti: The Organization of American States and United Nations Experience: 1991-1995 (unpublished manuscript, on file with author); Teson, supra note 14, at 355-56.

41. See Roth, supra note 26 , at 511-12.

42. Cf. id. (noting that Aristide's elected status and the military's "violent conduct and unsavory history" combined to create a situation in which there was "no contest over the mandate to articulate the will of the 'legitimate' government").

43. As Brad Roth observed prior to the U.N. authorization of military intervention in Haiti, "in all likelihood, fulfillment of requests for armed assistance would not in this case be deemed a violation of international law." Id. at 511.

44. See S.C. Res. 940, U.N. SCOR, 49th Sess., 3413th mtg. at 2, U.N. Doc. S/RES/940 (1994) ("[d]etermining that the situation in Haiti continues to constitute a threat to peace and security in the region," and, "[a]cting under Chapter VII of the Charter," authorizing "Member States ... to use all necessary means to facilitate" the restoration of the Aristide government).

45. The resolution cited two letters, one from Aristide (S/1994/905, annex), and another from Haiti's Permanent Representative to the United Nations (S/1994/910). Both letters implicitly supported U.N.-authorized military intervention. Id. 
tion. $^{46}$ Thus, it seems clear that no right of forcible pro-democratic intervention has yet emerged. International law continues to place considerable importance on effective control as an indicator of a government's authority to act in the name of the state. ${ }^{47}$

At the same time, however, intervention to restore or install a democratic government is likely to receive much more sympathetic treatment than most other forms of military intervention, at least if it appears that the intervenors are not motivated by hegemonic or ideological ambitions. In a number of recent cases, both international organizations and individual states have objected vigorously to military coups against elected governments, and have taken limited steps to oppose such coups. ${ }^{48}$ Moreover, both the Organization for Security and Cooperation in Europe (OSCE) and the OAS have pledged to take action against the unconstitutional overthrow of a democratic government within their respective regions. ${ }^{49}$ While the growing consensus on the importance of democratic governance has

46. In adopting Resolution 940, the Security Council considered the options outlined in the Report of the Secretary-General on the United Nations Mission in Haiti, U.N. Doc. S/1994/828 (1994). In that report, the Secretary-General states that an expanded U.N. force should operate with the consent of the legitimate authorities in Haiti, but also notes that such a force "would have to use coercive means in order to fulfill its mandate," and that it would therefore "be necessary for the Security Council to act under Chapter VII of the Charter in authorizing its mandate." Id. para. 8. During the debate on Resolution 940, several states' representatives noted that Aristide's consent to intervention was an important factor supporting the decision to intervene, but no one identified it as either a necessary or a sufficient legal basis for intervention. See U.N. SCOR, 49th Sess., 3413th mtg. at 17, 19, 23, 24, U.N. Doc., S/PV.3413 (1994) (statements of the representatives of Argentina, Spain, the Russian Federation, and the Czech Republic).

47. Thus, few states considered Endara's consent legally significant when the United States invoked the support of Panama's President-elect, Guillermo Endara, as one of several grounds allegedly justifying U.S. military intervention in Panama. See Abraham D. Sofaer, Remarks, Panel on The Panamanian Revolution: Diplomacy, War and Self-Determination in Panama, 84 AM. SOC'Y INT'L L. PROCEEDINGS 182, 183 (1990).

48. See Acevedo, supra note 33, at 141 (noting OAS criticism of "the coup in Suriname in December 1990, the attempted coup in Venezuela in February 1992, and the so-called autogolpe by the constitutional president of Peru in April 1992 and of Guatemala in May 1993"); Reisman, supra note 7, at 797-98.

49. See Document of the Moscow Meeting of the Conference on the Human Dimension of the CSCE, 30 I.L.M. 1670, 1677 (1991) (pledging "to make democratic advances irreversible," and to "support vigorously" any democratic government subject to an unconstitutional overthrow); The Santiago Commitment to Democracy and the Renewal of the Inter-American System, O.A.S. General Assembly, 3d plenary sess. (adopted June 4, 1991), at 1, O.A.S. Doc. OEA/Ser.P/XXI.O.2 (1991) (declaring democracy to be the only acceptable form of government for the hemisphere and mandating prompt consideration of collective measures to restore democracy in any member country subject to an illegal seizure of power); Resolution on Representative Democracy, O.A.S. General Assembly, 5th plen. sess. (adopted June 5, 1991), AG/RES. 1080 (XXI-0/91), O.A.S. Doc. OEA/Ser.P/XXI.O.2 (1991). 
not translated into acceptance of military intervention in most cases, it does make it easier to employ non-coercive sanctions, and in rare cases, as in Haiti, to obtain Security Council authorization for more coercive measures.

\section{B. Equilibrium Between the Government and Its Adversaries}

In many cases of internal conflict, the Government and its adversaries may achieve a rough balance of power with each controlling a significant portion of the state and its population. Juridical opinion and state practice in such cases are varied and often contradictory. ${ }^{50}$ In theory, external assistance to either side, particularly through military intervention, may violate the right of the people of the state to determine the outcome of the conflict themselves. ${ }^{52}$ This theory is problematic, since it privileges an outcome based on the relative strength of the combatants over an outcome determined by the popular support each faction holds or the type of regime each faction is likely to establish should it gain full control of the state. Nonetheless, other approaches may be even more problematic, requiring as they do subjective evaluations by potentially biased external actors of the human rights credentials or democratic prospects of contenders for power in another country.

In practice, most states continue to accord substantial deference to the will of a recognized, incumbent government, even after it arguably lost control of a substantial portion of the state, so long as the government retains control over the capital city and does not appear to be in imminent danger of collapse. ${ }^{52}$ In virtually all such cases, however, it is possible for the government to allege that the opposition forces are receiving substantial external assistance from third states in violation of the non-intervention principle. Accordingly the government can claim a right to receive outside assistance, including troops, as a form of counter-intervention. ${ }^{53}$ This claimed right is related to but independent of any authority the government might otherwise have to consent to foreign military intervention. It rests on the premise that aid in such circumstances is not a form of intervention requiring legitimation, but rather a means to neutralize an unlawful, prior intervention, thus returning control over the state's po-

50. See Brownlie, supra note 20 , at $326-27$.

51. See, e.g., Schachter, supra note 16, at 1641; Moore, supra note 16, at 196.

52. See Doswald-Beck, supra note 6, at 197-98.

53. For a discussion of the right of counterintervention, see generally John A. Perkins, The Right of Counterintervention, 17 GA. J. INT'L \& COMP. L. 171 (1986). 
litical future to internal actors to the extent that is possible. ${ }^{54}$ Alternatively, aid may be characterized as a form of collective self-defense against external aggression directed by third states against the state of the requesting government. ${ }^{55}$

Unfortunately, the ease with which individual states may invoke asserted rights of counterintervention or collective self-defense makes it difficult to assess the relative significance of consent as an independent justification in most instances of intervention on behalf of embattled but still functioning incumbent governments. This is particularly true for the many cases in which discussions of legal justification were openly colored by Cold War tensions. The 1958 U.S. intervention in Lebanon provides a case in point. The Lebanese government, which was facing a substantial and growing insurrection, alleged that the United Arab Republic was unlawfully supporting the insurrectionists. The United States sent troops to assist the Lebanese government, at its request. The United States, supported by other western countries, argued that it was entirely in accordance with the United Nations Charter to provide such assistance in the face of "an insurrection stimulated and assisted from outside ..."s6 The Soviet Union, however, with support from a number of states in the General Assembly, characterized the insurrection in Lebanon as "a popular movement against the "reactionary government" of the Lebanese President, and attacked U.S. involvement as a violation of the nonintervention principle. ${ }^{57}$

In most such cases, it is difficult to ascertain with any certainty the facts surrounding a government's claim that its internal armed opposition is receiving significant external support. Even in cases where the facts were reasonably clear, Cold War constraints and concerns about intruding on a state's domestic jurisdiction typically precluded the United Nations from taking any effective action against external intervention. As a result, states commonly acted as if incumbent governments had a virtually unlimited right to obtain help from third states in seeking to suppress internal rebellions. ${ }^{58}$ With the

54. See Schachter, supra note 16, at 1642; Henkin, supra note 20, at 63-64.

55. See OSCAR SCHACHTER, INTERNATIONAL LAW IN THEORY AND PRACTICE 159 (1991) (noting that if aid to rebel forces amounts to an armed attack, a counterinterventionary response may be an instance of legitimate collective self-defense).

56. U.N. SCOR, 13th Sess., 827th mtg. at 6, U.N. Doc. S/PV.827 (1958); see DoswaldBeck, supra note 6; at 214-15.

57. See Doswald-Beck, supra note 6, at 216.

58. See Farer, supra note 17, at 319. 
end of the Cold War, the members of the Security Council now periodically find it possible to agree on the undesirability of external intervention in particular cases. When such agreement is possible, the Council often imposes mandatory arms embargos on all parties to the conflict. $^{59}$ But for the most part, the Council only adopts coercive measures when the incumbent government disappears or becomes simply one of many warring factions. ${ }^{60}$ Until that point is reached, third states continue to act as if they have a broad right to aid incumbent governments, provided those governments can plausibly allege that the rebels are receiving external assistance.

Unlike individual states, however, international organizations generally prefer not to rely on counterintervention or collective selfdefense as a justification for military intervention in internal conflicts. Instead, both the United Nations and regional organizations usually proclaim that they are neutral with regard to the merits of the underlying conflict. They strive, at least publicly, to avoid siding openly with either the government or its opposition. In general, they seek to play a mediating or peacekeeping function. ${ }^{61}$

Accordingly, such organizations often face a number of problems specific to intervention under this posture. The first issue they must confront is whose consent must be obtained for intervention. As a prudential matter, both the United Nations and regional organizations will ordinarily seek the consent of each of the primary warring parties before sending troops into the middle of an internal conflict. ${ }^{62}$ The applicable legal requirement, however, is consent of the territorial state. In some cases that requirement may be satisfied by the consent of the incumbent government, even if its authority has been substantially undermined by a significant armed rebellion. In evaluating the incumbent government's authority in this context, even wide-spread recognition of a government is not by itself disposi-

59. See, e.g., S.C. Res. 788, U.N. SCOR, 47th Sess., 3138th mtg. at 3, U.N. Doc. 3/RES/788 (1992) (imposing a mandatory embargo on "all deliveries of weapons and military equipment to Liberia" except deliveries to West African peacekeeping forces); S.C. Res. 713, U.N. SCOR, 46th Sess., 3009th mtg. at 3, U.N. Doc. S/RES/713 (1991) (imposing a weapons embargo on the former Yugoslavia).

60. See Wippman, supra note 15 , at 473 .

61. See, e.g., Tom J. Farer, Intervention in Unnatural Humanitarian Emergencies: Lessons of the First Phase, 18 HUM. RTS. Q. 1, 4-7 (1996); Wippman, supra note 15, at 25-26, 34-35.

62. See Lori Damrosch, Introduction, in ENFORCING RESTRAINT: COLLECTIVE INTERVENTION IN INTERNAL CONFLICTS 1, 11 (L. Damrosch ed., 1993) ("obtaining the effective consent of all the combatants has seemed the best way to ensure that they can carry out a feasible mission."). 
tive. States and international organizations are slow to withdraw recognition from an incumbent government, even when that government has lost control of much of the state. ${ }^{63}$ Indeed, premature withdrawal of recognition might be seen as illicit support for the rebel forces. ${ }^{64}$ But, the failure to withdraw recognition does not automatically translate into acceptance of the recognized government's authority to invite external military intervention on its own behalf. As a legal matter, whether a government is entitled to give unilateral consent to the deployment of troops, even for peacekeeping purposes, depends more on the extent of the government's control of the state than on the breadth of its recognition in the international community. As enunciated by the British Foreign Secretary, the test is whether the regime in power "exercise[s] effective control of the territory of the State concerned, and seem[s] likely to continue to do so.."65

Again, however, the question of control is complicated by the common existence of illicit foreign intervention. In Cyprus, for example, the resolutions authorizing the continued deployment of U.N. peacekeeping forces cite only the consent of the recognized Greek Cypriot dominated Government, even though Turkish Cypriots have long controlled more than one third of the state. ${ }^{66}$ The U.N.'s formal reliance on government consent reflects not only the fact that the Government still controls most of Cyprus, but also the fact that the government would control the entire state but for Turkish military intervention. ${ }^{67}$

In general, when a government faces substantial armed opposition, both the U.N. and regional organizations, more so than individual states, appear to have considerable leeway in determining whether to rely on the consent of the government as a sufficient legal basis for intervention. For example, in 1981 the Organization of Af-

63. See Doswald-Beck, supra note 6, at 197-98.

64. See 1 L. OPPENHEIM, supra note 5, para. 74, at 134-37.

65. See Speech of the British Foreign Secretary, Lord Carrington to the House of Lords, 408 PARL. DEB., H.L. (5th sev.) 1121-22 (1980), cited in Doswald-Beck, supra note 6, at 194. The Foreign Secretary was discussing Britain's decision to dispense with formal recognition in favor of a policy that allows recognition of regimes that take power unconstitutionally to be determined by the nature of the United Kingdom's dealings with those regimes. However, the de facto control test he described is equally applicable to determinations of a regime's authority to invite external military intervention. See Doswald-Beck, supra note 6, at 194-96.

66. See, e.g., S.C. Res. 723, U.N. SCOR, 46th Sess., 3022nd mtg., S/RES/723 (1991).

67. For a discussion of Turkish military intervention and the legal issues surrounding it, see David Wippman, International Law and Ethnic Conflict on Cyprus, 27 TEX INT'L L.J. 1 (1995). 
rican Unity (OAU) dispatched an Inter-African Force to conduct peacekeeping operations in Chad on the basis of a request from the Chadian Government, even though that Government's position was so precarious that the rebel forces overthrew the Government the following year. ${ }^{68}$ Similarly, the Arab League relied on Lebanese Government consent as the basis for intervening in that country's civil war, even though the Government's authority in much of the country was tenuous at best. ${ }^{69}$ In such cases most states seem willing to defer to the judgment of the appropriate regional organization. ${ }^{70}$

\section{Government As Warring Faction}

In some civil wars the government loses control over most of the country, ceases to exercise any substantial administrative or governmental functions, and becomes in effect simply one among a number of warring factions. For example, President Samuel Doe's government in Liberia lost control of most of the state to rebel forces following a rebellion that began on December 24, 1989." By the summer of 1990 , most government ministers had fled the country, and all state institutions had ground to a halt. The rebels exercised military but not administrative control over most of Liberia, with the exception of a portion of the capital still in the hands of what remained of Doe's military. ${ }^{72}$

Liberia's neighbors watched the growing chaos with some dismay, fearing it might spread throughout the region. Nigeria, the dominant regional power and a supporter of the Doe government, pressed for regional military action to restore order in Liberia. ${ }^{73}$ Doe welcomed the Nigerian initiative, as did Prince Johnson, the leader of the smaller of the two rebel factions then battling Doe's forces for control of the capital. However, Charles Taylor, the leader of the

68. See generally Amadu Sesay, The Limits of Peace-Keeping by a Regional Organization: The OAU Peace-Keeping Force in Chad, CONFLICT Q. (Winter 1991).

69. See generally The Legal Basis of the Arab League in Lebanon, in ISTVAN PoGANY, THE ARAB LEAGUE AND PEACEKEEPING IN THE LEBANON at 93-107 (1987).

70. Some of the possible reasons for such deference are discussed at text accompanying note 92 infra.

71. For a more detailed treatment of the Liberian civil war, see David Wippman, Enforcing the Peace: ECOWAS and the Liberian Civil War, in ENFORCING RESTRAINT: COLLECTIVE INTERVENTION IN INTERNAL CONFLICTS 157 (L. Damrosch ed., 1991).

72. See id. at 158.

73. See Anthony Chukwukaa Ofodile, The Legality of ECOWAS Intervention in Liberia, 32 COLUM. J. TRANSNAT'L L. 381, 383-84 (1994). 
main rebel force, strongly opposed external intervention. ${ }^{74}$ Taylor believed that given time his forces could take control of the entire state, and that any regional intervention led by Nigeria would support the failing Doe regime at Taylor's expense. ${ }^{75}$

Although Liberia's U.N. representative sought to place the Liberian crisis on the Security Council's agenda, the Council took no action. ${ }^{76}$ In August 1990, five states, operating under the auspices of the Economic Community of West African States (ECOWAS), sent several thousand troops into Monrovia. The troops were instructed to act as a peacekeeping force, to the extent possible. In keeping with this ostensible mission, the "peacekeepers" were designated as the Economic Community of West African States Monitoring Group (ECOMOG). ${ }^{n}$ Taylor did not view ECOMOG as a neutral peacekeeping force, however, and his forces attacked ECOMOG on its arrival. ECOMOG then launched a military offensive to expel Taylor's forces from Monrovia and to secure the capital. ${ }^{78}$

This action and subsequent offensives against Taylor's forces are not easy to reconcile with international law. ECOWAS did not have Security Council authorization when it sent troops into Liberia. It did not have the consent of the dominant warring faction, which stated in advance that it would treat an ECOWAS military intervention as an illegal foreign invasion. Thus, this was not a classic peacekeeping operation in which the intervening force obtains the advance consent of the primary warring parties.

At least one author, Professor Georg Nolte, has argued forcefully that President Doe's consent to the intervention was sufficient legal authority for it. ${ }^{79}$ Nolte contends that it is "irrelevant" that Doe had been reduced to a "minor contender for power" at the time he gave his consent to the intervention. ${ }^{80}$ His government was still the recognized government of Liberia, and was "capable, by agreeing to a cease-fire with an otherwise rival faction, of paving the way for entry

74. See Wippman, supra note 15 , at 167 ; Ofodile, supra note 73 , at $384-85$.

75. See U.N. GAOR, 45th Sess., 27th mtg. at 61, U.N. Doc. A/45/PV. 27 (1990).

76. See U.N. GAOR, 45th Sess., 27th mtg. at 61, U.N. Doc. A/45/PV.27 (1990); U.N. SCOR, 2974 mtg. at 3, U.N. Doc. S/PV. 2974 (1991).

77. See Wippman, supra note 15 , at 167-68.

78. See id. at 168-69.

79. Georg Nolte, Restoring Peace by Regional Action: International Legal Aspects of the Liberian Conflict, 53 ZEITSCHRIFT FÜR AUSLANDISCHES ÖFFENTLICHES RECHT UND VOLKKERRECHT 603 (1993).

80. Id. at 625 . 
of the intervention forces into his country." ${ }^{81}$ Nolte recognizes that such a rule, allowing an essentially defunct government to invite external military intervention to prevent an adversary from taking power, might be abused by neighboring states with hegemonic aspirations, and might lead to an internationalization of a domestic conflict. Nolte argues, however, that the regional framework for intervention provides "the necessary degree of impartiality and the chance of containment of the conflict," and that in situations comparable to Liberia's, it is necessary to balance the goals served by the nonintervention principle with the need to further humanitarian aims. ${ }^{82}$

Thus, Nolte's position is that Doe's consent was sufficient legal justification for regional intervention in Liberia, especially in light of the humanitarian aims of that intervention. This position is logically consistent with the Security Council's reaction to the ECOWAS intervention. Although the Council never formally authorized military action, months after the initial intervention it did issue statements commending ECOWAS for its efforts to restore peace in Liberia. ${ }^{83}$ Since the conventional view is that only prior authorization will suffice to legitimize a regional enforcement action, the Council's post hoc approval suggests that the Council considered the ECOWAS intervention to be a consent-based peacekeeping operation. Moreover, during debate on a later resolution authorizing sanctions against Taylor's forces, various members of the Council expressly characterized ECOMOG as a "peacekeeping force." definition, is an operation undertaken with the consent of the territorial state, and since Taylor did not consent, one could read this characterization of ECOMOG as an implicit claim that Doe acting alone had the legal authority to consent to ECOMOG's deployment.

Nonetheless, it is difficult to conclude from the facts of this case that a government, reduced to the status of one among several warring parties, can unilaterally consent to an external intervention, even when the intervention is carried out under the auspices of a regional or subregional organization. ECOWAS itself did not cite Doe's con-

81. Id.

82. Id. at 623-24.

83. See Note by the President of the Security Council, S/22133, January 22, 1991; Note by the President of the Security Council, S/23886, May 7, 1992.

84. See generally Security Council, Provisional Verbatim Record of the Three Thousand One Hundred and Thirty-eighth Meeting, S/PV.3138, November 19, 1992; Wippman, supra note 15 , at 185 . 
sent as a legal basis for intervention, ${ }^{85}$ nor did individual states. Given the abysmal nature of the Doe regime, the breadth of opposition to it throughout the country, and the personal ties between Doe and the Nigerian President, reliance on Doe's consent would have been politically intolerable. It would also have run contrary to ECOMOG's claim to be a neutral interposition force. That claim was never entirely credible, since ECOMOG from the start was forced into an adversarial posture with Charles Taylor. But even though ECOMOG intervened against Taylor, it did not intervene for Doe. It made no effort to restore Doe to power. Instead, ECOMOG, and ECOWAS more generally, sought from the outset to arrange internationally monitored elections as the basis for resolving the conflict, and deliberately excluded Doe as a possible candidate in such elections. ${ }^{86}$ Indeed, it was precisely because ECOWAS pursued a strategy of national reconciliation through democratic elections that the intervention attracted international support.

By itself, this does not mean that ECOWAS could not rely on Doe's consent as the legal basis for intervention. ${ }^{87}$ When the United Nations first intervened in the Congo, it relied in large part on the beleaguered government's consent, even though the U.N. claimed to be neutral as between the internal warring factions. ${ }^{88}$ But in the Congo, as in other cases where a multinational intervention force relied on a teetering government's consent, an illicit prior intervention (in that case by Belgium) arguably justified external aid to the government. ${ }^{89}$ A similar argument could have been made in Liberia since Taylor received substantial support from Libya, Burkina Faso, and Côte d'Ivoire. ${ }^{90}$ But ECOWAS chose not to take that position, preferring to rely instead on a humanitarian justification.

Overall, there are good reasons why Doe's consent should be deemed insufficient as a legal justification. Unlike Aristide, Doe lacked the legitimacy that comes with the acquisition of power through internationally monitored elections. Accordingly, once Doe

85. In fact, ECOWAS stressed that its intervention was not designed "to save one part." See U.N. SCOR, Annex 1, at 3, U.N. Doc. S/21485 (1990).

86. See Christopher J. Borgen, The Theory and Practice of Regional Organization Intervention in Civil Wars, 26 N.Y.U. J. INT'LL. \& POL. 797, 817 (1994).

87. See Nolte, supra note 79 , at 626.

88. See S.C. Res. 143, U.N. SCOR, 15th Sess., 873d mtg., U.N. Doc. S/4387 (1960).

89. For a brief description of events in the Congo, see THOMAS M. FRANCK, NATION Against Nation: What HAPPENED to tHE U.N. DREAM AND What THE U.S. CAN Do ABOUT IT 174-77 (1985).

90. See Wippman, supra note 15 , at 188. 
was effectively reduced from head of state to head of a minor warring faction, his authority to speak for the state was nominal and purely formal. Doe's authority rested on the tenuous prop of external recognition. Though not withdrawn, such recognition says little in this context about outside states' views of Doe's authority, and nothing at all about the relationship between effective control and political community that normally underpins a government's claim in international law to be able to invite intervention on behalf of the state.

In the end, Doe's invitation adds only a thin patina of legitimacy to the force of the humanitarian arguments for intervention." If those arguments are not sufficient in and of themselves to warrant intervention, it is difficult to conclude, as a matter of law or policy, that the invitation of one faction, even if it is the faction that previously controlled the government, should materially alter the legal calculus.

This is not to say that regional organizations should not have a substantial margin of appreciation when determining whether a government's political and military position has deteriorated to the point that it no longer possesses sufficient authority to invite outside intervention. States typically do, and should, accord substantial deference to judgments by regional organizations with regard to the standing of a particular government within their region. There are several reasons why such deference is appropriate. First, as noted earlier, the process of multilateral decision-making, which requires achievement of a consensus among states with diverse interests, acts as a screen for purely self-interested interventions. Second, the member states of regional organizations have assented, at least to some degree, to the decision-making procedures at issue. Third, the member states are likely to have a greater expertise on the issues driving the conflict and greater familiarity with the warring parties than extra-regional actors. Regional organizations may thus be in a better position to evaluate and choose among available courses of action than states operating from a greater cultural and political distance.

There are, of course, some countervailing considerations. In particular, the very proximity that affords regional organizations a better understanding of local conditions than more distant states may also generate a greater degree of bias or self-interest than might be expected in other states. Moreover, it is possible in particular cases

91. Accord Borgen, supra note 86 , at 818 ("Since ECOWAS marginalized the Doe government and forged a future for Liberia that did not envision Doe at all, the legitimacy of its action cannot be argued to be based on the consent of the parties."). 
that a regional organization may simply act as a vehicle to conceal the driving interests of the organization's most powerful state. Most important, regional organizations typically lack the will, the resources, or both to intervene effectively in large-scale internal conflicts. ${ }^{92}$

The dangers of biased or hegemonic interventions are real, but they are probably less significant now than during the Cold War when the United States undermined the perceived utility of regional collective decision making processes through its efforts to use the OAS (and on one occasion, the Organization of Eastern Caribbean States) as vehicles to legitimize ideologically motivated interventions in Latin America and the Caribbean..$^{93}$ Moreover, these dangers can be mitigated through careful U.N. oversight of regional interventions. ${ }^{94}$ The larger problem is one of capabilities. Only a few subglobal organizations, NATO in particular, have the logistical and financial capacity to conduct effective large-scale military operations in distant countries. But the member states in those organizations seldom see a vital national interest at stake in contemporary internal conflicts, and thus lack the will to engage in the sustained peacekeeping, peace enforcement, and peacebuilding measures needed to stabilize war-torn countries. Fears of regional instability and weaker structures of public accountability may give smaller regional and subregional organizations (such as ECOWAS) the political will to intervene in internal conflicts, and an ability to take casualties well past the point that would drive out less motivated intervenors. But such organizations seldom have the resources, experience, or credibility with the warring parties to intervene effectively. ${ }^{95}$

The obvious response to this dilemma is for the better endowed international organizations to assist the weaker but more motivated

92. See Jeffrey Laurenti, The Regionals and the U.N.: Keystone Cops?, Address at the conference on "The United Nations, Regional Organizations, and Military Operations" hosted by the Center on Law, Ethics, and National Security, Duke University School of Law, April 1213, 1996 (on file with the Duke Journal of Comparative \& International Law).

93. See, e.g., Farer, supra note 17, at 333-35.

94. The United Nations dispatched peacekeepers to Liberia in part because of concerns over the neutrality of ECOWAS forces. See S.C. Res. 866, U.N. SCOR, 48th Sess., 3281st mtg. at 2, U.N. Doc. S/RES/866 (1993); Binaifer Nowrojee, Recent Developments: Joining Forces: United Nations and Regional Peacekeeping-Lessons from Liberia, 8 HARV. HUM. RTS. J. 129 (1995). The United Nations has also sent peacekeepers to the Caucasus, in part to keep watch over peacekeeping actions conducted by forces from the Commonwealth of Independent States. See James Meek, Peacekeeping: U.N. Rules Out Special Status for Russians, THE GUARDIAN (Manchester, Eng.), April 5, 1994, at 9.

95. See Laurenti, supra note 92. 
regional organizations to intervene constructively. That approach has been attempted in various conflicts. In Liberia, for example, the United Nations and individual states have provided various forms of assistance to ECOWAS, while leaving to ECOWAS the dominant role in attempting to establish peace. To date, the support given to ECOWAS has been far less than the organization needed to compensate for its own limited resources. ${ }^{96}$ But as the international community acquires more experience in ending internal conflicts using coordinated efforts by various international organizations, the record in this area may improve.

On balance, it seems appropriate as a legal matter to continue to accord regional organizations a reasonable margin of appreciation in evaluating the authority of particular governments to invite intervention in close cases. Even so, justifications other than governmental consent should be sought when no single faction can credibly claim to speak for the state. One possibility, of course, is consent from all of the principal warring factions. To the extent that international law treats control of the state as a sufficient basis for expressing the state's consent to external military intervention, it seems reasonable to conclude that the collective consent of the various warring factions, which together control the state as a whole, constitutes the best available alternative to consent by a recognized, effective government. ${ }^{97}$ In many cases, it may be politically or morally unattractive to accord substantial legal significance to the will of one or more faction leaders, particularly if such leaders command no significant popular allegiance, rule by terror, and exercise no real governmental functions in their areas of military predominance. ${ }^{98}$ Unfortunately, external actors wishing to end a protracted and bloody internal conflict often have no choice but to accept such leaders as speaking for the territory and population under their control. ${ }^{99}$

96. See Nowrojee, supra note 94 , at 147-48.

97. See ANn VAN WYNEn Thomas \& A. J. ThOMAS, JR., NON-INTERVENTION: THE LAW AND ITS IMPORT IN THE AMERICAS 215, 221 (1956) (if all parties to an internal struggle request intervention, "the legality of the intervention would then be based upon the total consent of the state").

98. See David Wippman, Treaty-Based Intervention: Who Can Say No?, 62 U. CHI. L. REV. 607, 657 (1995).

99. See, e.g., Statement of Roy S. Lee, 28 CORNELL INT'L L. J. 643 (1995) ("Essentially you have to negotiate with somebody in power."). 


\section{Collapse of Internal Authority}

In some cases, conflict reaches a level of intensity in which the forces of the incumbent government are routed, and no other internal source of authority exercises any meaningful administrative or governmental functions. It is doubtful that this situation presents a significantly different legal posture than a situation in which the government becomes simply one among a number of warring factions. Some authors have suggested, however, that in a situation of complete breakdown of internal authority, regional organizations have a special competence to intervene to restore order..$^{100}$

It could be argued that in such a case military action by a regional organization to restore order falls within the bounds of regional authority to deal with problems "appropriate for regional action" pursuant to Chapter VIII of the Charter. ${ }^{101}$ Absent any viable internal authority, the argument goes, intervention designed to restore conditions under which the population of the state can establish a government of its choosing would not be action against a state, and so would not constitute enforcement action of the sort that would have to be authorized by the Security Council pursuant to Article 53 of the Charter. ${ }^{102}$ Accordingly, consent in such cases might be treated as unnecessary. Alternatively, consent in such cases might be presumed. Under this approach, the assumption would be that intervention in such circumstances would be so clearly in the interest of the affected state that the state, or the people of the state, would certainly consent to such intervention if they could. ${ }^{103}$ Either way, interventions to restore order could be deemed to fall within the gray area between Article 52's peaceful dispute resolution mechanisms and Article 53's enforcement action.

A variation on this argument would be that in a situation of complete internal breakdown, the highest surviving official of the

100. See John Norton Moore, Grenada and the International Double Standard, 78 AM. J. INT"L L. 145, 154-56 (1984) ("there is substantial authority that regional peacekeeping actions undertaken in a setting of breakdown of authority are lawful under the Charter."); see also 20 U.N. SCOR, 1220th mtg. at 15, 16-17, U.N. Doc. S/PV.1220 (1965); 20 U.N. SCOR, 122d mtg. at 3, 4-5, U.N. Doc. S/PV.1222 (1965) (statements of U.S. Ambassadors Stevenson and Yost).

101. Article 52 of the U.N. Charter provides: "Nothing in the present Charter precludes the existence of regional arrangements or agencies for dealing with such matters relating to the maintenance of international peace and security as are appropriate for regional action, provided that such arrangements or agencies and their activities are consistent with the Purposes and Principles of the United Nations."

102. See Moore, supra note 100 , at 154 .

103. See Ago, supra note 1 , at 36. 
vanished government should have the authority to invite external intervention to restore order. ${ }^{104}$ This situation arguably differs from the situation where a government's status is reduced to one of several warring factions, because the surviving official supposedly speaks against a background of anarchy rather than as the representative of one of several factions each claiming the right to speak for the state.

The United States invoked both variations of the argument in support of its 1983 invasion of Grenada. The United States claimed that anarchy reigned at the moment of intervention, and that swift action was necessary to restore order and to protect U.S. nationals resident in Grenada. ${ }^{105}$ To support its decision, the United States invoked, inter alia, the authorization of the Organization of Eastern Caribbean States, claiming that it had authority under Chapter VIII of the U.N. Charter to respond to disorder in a member state. ${ }^{106}$ The United States also relied on an invitation to intervene issued by the Governor-General of Grenada. ${ }^{107}$ Even though the GovernorGeneral's authority within Grenada was largely ceremonial, ${ }^{108}$ the United States argued that his consent carried substantial weight in the absence of colorable claims by other internal actors to speak for the state. However, neither of these justifications, either individually or in tandem with the alleged threat to U.S. nationals, proved persuasive to most states. ${ }^{109}$

The notion that states may intervene to substitute an orderly democratic process for anarchic violence as a means to reorder a state's internal political structures is an attractive one, at least on the surface. In theory, an intervention of that sort, if effective and accomplished at a reasonable cost to the affected state, could only benefit the people of that state. ${ }^{110}$ Under the conventional under-

104. See Moore, supra note 100, at 153 n. 26, 159-61 (arguing that the Governor-General of Grenada had more authority to speak for Grenada than any other official at the time of the U.S. invasion of Grenada).

105. See Statement of the Honorable Kenneth W. Dam, Deputy Secretary of State, before the Committee on Foreign Affairs, U.S. House of Representatives 2 (Nov. 2, 1983), reprinted in 78 AM. J. INT'L L. 200, 200-02 (1984).

106. See id. at 203.

107. See id.

108. See Christopher Joyner, The United States Action in Grenada: Reflections on the Lawfulness of Invasion, 78 AM. J. INT'L L. 131, 139 (1984).

109. The U.S. invasion was condemned by a substantial majority of the U.N. General Assembly. See G.A. Res. 38/7, U.N. GAOR, 38th Sess., Supp. No. 47, U.N. Doc. A/38/47 (1983).

110. See, e.g., Malvina Halberstam, The Copenhagen Document: Intervention in Support of Democracy, 34 HARV. INT'L L.J. 163, 167 (1993) (arguing that pro-democratic intervention is not against "but in support of the 'territorial integrity' and 'political independence' of a state"); 
standing of the U.N. Charter, however, any uninvited military intervention that is not undertaken in self-defense or authorized by the Security Council is illegal. ${ }^{111}$ Moreover, the risks of abuse associated with a broad license to restore order are substantial, since there will often be a significant, though temporary, vacuum of authority between the overthrow of the incumbent government and the establishment of a successor government.

It might be appropriate, however, to create an exception for cases of protracted anarchy, in which all government functions cease for an extended period, and the warring factions are unable or unwilling to exercise any administrative functions even within the territory they control. ${ }^{112}$ Possession of a government is an element and arguably a duty of statehood. ${ }^{113}$ The temporary absence of a government cannot by itself suffice to trigger intervention, because internal actors must be given some opportunity to reestablish order on their own terms. ${ }^{114}$ At some point, however, the prolonged absence of any government may constitute an abdication of the responsibilities of statehood sufficient to warrant external intervention designed to enable the citizens of the state to resume control over their affairs, and to put an end to destructive and pointless conflict. ${ }^{115}$

One problem, of course, is determining when that point is reached. The Security Council can decide at any time that the effects of anarchy are intolerable and authorize military intervention simply by finding that the "magnitude of the human tragedy" created by such conditions constitutes a threat to international peace. That, af-

Anthony D'Amato, The Invasion of Panama Was a Lawful Response to Tyranny, 84 AM. J. INT'L L. 516 (1990); W. Michael Reisman, Coercion and Self-Determination: Construing Charter Article 2(4), 78 AM. J. INT'L L. 642, 644-45 (1984) (The critical question in a decentralized system is not whether coercion has been applied, but whether it was applied in support of or against community order and basic policies ....").

111. See generally Louis Henkin, Use of Force: Law and U.S. Policy, in RIGHT V. MIGHT: INTERNATIONAL LAW AND THE USE OF FORCE 37 (2d ed. 1991).

112. See THOMAS \& THOMAS, supra note 97 , at 220-21.

113. See id. at 220 ("It is the duty of a population to provide itself with a government."); see also 1 RESTATEMENT OF THE FOREIGN RELATIONS LAW OF THE U.S. \& $201 \mathrm{cmt}$. f, at 73 (1987) ("A state need not have any particular form of government, but there must be some authority exercising governmental functions and able to represent the entity in international affairs.").

114. See THOMAs \& THOMAS, supra note 97 , at 220-21.

115. See id. at 221 ("[I]n the event a nation falls into anarchy, intervention is legal only where there is a prolonged entire absence of government."). But see Francis Boyle, et al., Intermational Lawlessness in Grenada, 78 AM. J. INT'L L. 172, 173 (1984) ("Even when it actually exists, chronic disorder in a country does not permit neighboring states to intervene for the purpose of reestablishing minimum public security, let alone imposing a democratic form of government."). 
ter all, was the basis for the U.N. authorized military intervention in Somalia. ${ }^{116}$

The question is whether regional organizations should have a similar margin of appreciation, either under a theory of presumed consent, or under the view that action to restore order in such cases does not constitute enforcement action under Chapter VIII of the U.N. Charter. Acceptance of a presumed consent theory, unless based on the terms of a regional organization's charter or some other treaty arrangement, would necessarily validate a similar intervention by a state acting unilaterally. That is a dangerous prospect since decisions by individual states are not subject to the checks and balances of a collective decision-making process. ${ }^{117}$ Accordingly, it seems better to conclude that such interventions, to the extent they are permissible at all without Security Council authorization, fall within the bounds of appropriate action by a regional organization.

\section{CONSENT AND ITS REVOCATION}

What happens when a state consents to intervention and then withdraws that consent? In the ordinary case, the answer is simple. Intervention by consent must remain within the bounds of that consent. Accordingly, if a generally effective incumbent government revokes its prior consent to an external military intervention, the intervenors must withdraw. ${ }^{118}$ Failure to do so amounts to an intervention against the will of the state.

There are circumstances, however, in which a different result might be reached. First, there is some uncertainty about the conditions under which even an effective government can lawfully revoke consent to the deployment of an international peacekeeping force. In 1967, Egypt withdrew its consent to the presence of the United Nations Emergency Force on Egyptian territory, thus paving the way for an Egyptian attack on Israel. ${ }^{119}$ The Secretary-General, after studying the legal aspects of the Egyptian position, concluded that the United Nations had no legal option but to withdraw. In his view, the deployment of peacekeepers required the continuous affirmative consent, or at least acquiescence, of the state in which the troops were

116. See S.C. Res. 794, U.N. SCOR, 46th Sess., 3145th mtg., U.N. Doc. S/RES/794 (1992).

117. See Ago, supra note 1, at 36 (arguing against acceptance of a theory of presumed consent on the ground that "cases of abuse would be too common").

118. For examples, see $i d$. at 32-33.

119. See FranCK, supra note 89, at 87-88; STEVEN R. RATNER, THE NEW U.N. PEACEKEEPING: BUILDING PEACE IN LANDS OF CONFLICT AFTER THE COLD WAR 38 (1995). 
placed. ${ }^{120}$

The Secretary-General's decision provoked considerable controversy. ${ }^{121}$ Some critics felt that Egypt's consent to the deployment, and its acceptance of a status of forces agreement with the U.N., created a legal obligation to permit the force to carry out its mission in accordance with the parties' prior agreement. ${ }^{12}$ To confer on any state the right to force a unilateral withdrawal of international peacekeepers at any time could stimulate strategic behavior, permitting one party to use peacekeepers as a means to buy time until that party is ready to resume a conflict previously suspended by agreement between the warring parties. On the other hand, deployment of military forces in a state's territory without its actual, contemporaneous consent impinges so directly on the autonomy of the state that the state presumably must retain, by virtue of its sovereignty, the right ultimately to revoke its consent and to force the intervenors to withdraw. The solution to this particular dilemma may lie in simply reading a requirement of reasonable notice into a state's right to revoke consent, thus giving all parties time to prepare for the peacekeepers' departure.

A similar problem arises when consent to intervention comes from two or more warring factions in an internal conflict, rather than from an effective government acting unilaterally. In such cases, states can reasonably rely on the consent of the various factions as collectively constituting the state's consent. ${ }^{123}$ Unfortunately, consent obtained in such fashion is often fragile. ${ }^{124}$ Almost inevitably, one faction may come to believe that the presence of external forces benefits the other side, even if the forces act as neutral peacekeepers. At that point, the faction perceiving itself as disadvantaged by intervention may withdraw consent, and even attack the would-be peacekeepers. Clearly, the peacekeepers have the right to defend themselves, but do they have the right to pursue their mission against

120. FRANCK, supra note 89, at 88-91; RATNER, supra note 119 , at 38.

121. See FRANCK, supra note 89, at 88-93; RATNER, supra note 119, at 38.

122. In a 1957 Aide Memoire, Secretary-General Dag Hammarskjöld recorded his understanding that Egypt had agreed to constrain its right to revoke consent to the deployment of UNEF. According to Hammarskjold, Egypt agreed that UNEF could stay until its mission was completed, as determined by both Egypt and the U.N. See Aide Memoire, reprinted in 6 I.L.M. 595 (1967).

123. See THOMAS \& THOMAs, supra note 97 , at $215,221$.

124. See RATNER, supra note 119 , at $38-41$ (analyzing problems with "decaying" consent in international peacekeeping operations). 
internal opposition? $?^{125}$

If one assumes that any coercive actions and even the continued presence of the peacekeepers requires either the contemporaneous consent of the state as a whole or Security Council authorization, then withdrawal of consent even by one among a number of factions may amount to the termination of consent as a legal basis for intervention. ${ }^{126}$ But if one assumes that the withdrawal of consent is as much an act of state will as the grant of consent in the first place, one could argue that revocation requires a collective decision, and that no single faction is entitled to revoke consent unilaterally.

Even if one follows the latter approach, however, consent may still prove to be a dubious basis for intervention, since some of the factions that gave their consent originally may splinter, disappear, or be replaced by new factions. On occasion, factions may reconstitute themselves under new names, precisely in order to escape any obligations they may previously have assumed. At some point, the continued presence of external forces will ordinarily require either renewed consent emanating from the new constellation of warring factions or Security Council authorization. ${ }^{127}$

When consent broke down as a basis for intervention in Somalia, the Security Council switched to enforcement action under Chapter VII. ${ }^{128}$ It did the same in the former Yugoslavia. ${ }^{129}$ By contrast, the consent of various warring factions to ECOWAS peacekeeping in $\mathrm{Li}$ beria has come and gone with some frequency over the last six years. Nonetheless, ECOWAS acts as if it has always had full consent, with

125. See OSCAR SCHACHTER, INTERNATIONAL LAW IN THEORY AND PRACTICE 408 (1991) (noting that U.N peacekeepers sometimes "stretch" the self-defense principle "far beyond its usual legal meaning," in part by combining a right to freedom of movement with a claimed "right to use arms in defense of positions occupied").

126. In many cases, parties dissatisfied with the activities of peacekeeping forces may simply engage in obstructionist tactics rather than explicitly withdraw consent. See RATNER, supra note 119 , at 38 . In such cases, peacekeepers may be forced to consider not simply the technical existence of consent, but also the "quality" of that consent, that is, the extent to which the principal parties to the conflict can be considered on balance committed to the peacekeeping process. See Id. at 39-41.

127. Cf. RATNER, supra note 119 , at 39 (arguing that the United Nations cannot force parties to comply with a peacekeeping agreement without impermissibly blurring the distinction between peacekeeping and enforcement).

128. See Lee, supra note 99, at 643; Jeffrey Clark, Debacle in Somalia: Failure of the Collective Response, in ENFORCING RESTRAINT: COLLECTIVE INTERVENTION IN INTERNAL CONFLICTS 205, 221-23 (1993).

129. See James B. Steinberg, International Involvement in the Yugoslavia Conflict, in ENFORCING RESTRAINT: COLIECTIVE INTERVENTION IN INTERNAL CONFLICTS 27, 50-55 (1993). 
the apparent blessing of the United Nations. In the end, this may be yet another area in which both the United Nations and regional organizations should be deemed to have a considerable margin for appreciation, that is, some leeway to decide whether a single faction's withdrawal of consent by itself fatally undermines the authority of the operation as a whole. ${ }^{130}$

Finally, there is considerable uncertainty over whether and under what conditions states may authorize external military intervention by treaty, even in the absence of any contemporaneous consent to the intervention. ${ }^{131}$ The issue is particularly intriguing as it relates to the intervention authority possessed by regional organizations or ad hoc coalitions of states. In a series of thoughtful articles, Professor Tom Farer urges us to consider the following hypothetical. Suppose that a group of democratic states in the Caribbean enters into a treaty with interested NATO members to protect democracy in the signatory states. In the event of an unconstitutional seizure of power in any one of those states, the other parties to the treaty are authorized to intervene militarily to restore the elected government, either at the request of the ousted elected officials, or by a two-thirds vote if communication with those officials proves impossible. Professor Farer's conclusion is that an intervention carried out pursuant to such a treaty would be lawful "[s]ince such an action is carried out with the previously expressed consent of the target state.",132

It could be argued, of course, that only the contemporaneous consent of the effective government can satisfy the peremptory norm against the use of force in international relations embodied in Article 2(4) of the U.N. Charter. But if the forces seizing power unconstitutionally have not yet consolidated their control over the country, or if, as in Haiti, the international community continues to recognize the former government as the legitimate state government, it seems fair

130. Cf. RATNER, supra note 119 , at $40-41$ (noting that in many cases of "decaying consent", states "neither insist upon enforcement authority from the Security Council to respond to many types of violations nor demand the termination of missions facing lack of compliance").

131. For a more detailed treatment of this subject, see Wippman, supra note 71, at 187-89.

132. Farer, supra note 17, at 332; see also Tom J. Farer, The United States as Guarantor of Democracy in the Caribbean Basin: Is There a Legal Way?, 10 HUM. RTs. Q. 157 (1988). For similar proposals, see Morton H. Halperin, Guaranteeing Democracy, 91 FOREIGN POL'Y 105, 121 (1993) (urging adoption of an "international guarantee" clause permitting forcible intervention to protect democracy upon "consensus of a group of guaranteeing powers designated in an agreement with a particular country"); Halberstam, supra note 110 (arguing that the Copenhagen Document can be construed to permit military intervention to protect democracy). 
to conclude that the usurpers acting alone should not be entitled to revoke the state's prior consent to intervention.

The question Professor Farer poses is not entirely hypothetical. A number of recent agreements designed to end protracted civil wars have come very close to authorizing outside states to employ force against any party that violates the agreement. ${ }^{133}$ It is too soon to tell, however, whether in the future such agreements might serve as a useful adjunct to existing legal mechanisms for the use of force in internal conflicts.

\section{CONCLUSION}

Despite its apparent simplicity, the principle that a state may validly consent to external military intervention turns out in practice to be fraught with difficulty. Once we move beyond the paradigm case of a recognized and effective government inviting intervention for sharply limited ends, it is extremely difficult to define precisely the cases in which invited interventions will be generally accepted. Previous state practice in this area is of only limited utility, since in most cases the reaction of states was strongly colored by Cold War considerations.

Nonetheless, it may be possible to offer a few generalizations, none of which are likely to prove surprising. In keeping with the traditional approach to intervention in internal conflicts, most states are strongly influenced by the extent to which an inviting authority exercises control of the state at the time an invitation to intervene is issued. Increasingly, however, states are prepared to consider the democratic legitimacy of an inviting authority as a counterbalance to considerations of power and effective control. Finally, in close cases,

133. See, e.g., Cotonou Agreement (July 25, 1993), art. 8, § 3, attached to Letter Dated 6 August 1993 from the Chargé d'Affaires A.I. of the Permanent Mission of Benin to the United Nations Addressed to the Secretary-General 7, U.N. Doc. S/26272 (1993), reprinted in REGIONAL PEACE-KEEPING AND INTERNATIONAL ENFORCEMENT: THE LIBERIAN CRISIS 343, 347 (Marc Weller ed., 1994) (authorizing ECOMOG to "resort to the use of its peaceenforcement powers" against violators of the agreement under specificed circumstances); Agreement on a Comprehensive Political Settlement of the Cambodia Conflict (October 30, 1991), art. 6, attached to Letter Dated 30 October 1991 from the Permanent Representatives of France and Indonesia to the United Nations addressed to the Secretary-General 10, U.N. Doc. A/46/608, S/23177 (1991), reprinted in 31 I.L.M. 180, 184 (1992) (delegating to the U.N. "all powers necessary to ensure the implementation of this Agreement"); General Framework for Peace in Bosnia and Herzegovina (December 14, 1995), Annex I, Art. 1, reprinted in 35 INT'L LEGAL MATERIALS 75, 92 (1996) (inviting the U.N. Security Council to establish a multinational military Implementation Force authorized to undertake "such enforcement action ... as may be necessary to ensure implementation" of the parties' agreement). 
states are likely to defer to the judgment of regional organizations, at least in those cases in which the United Nations itself is reluctant to get involved. 
